\title{
University Science Park Based Construction Mode of Innovation and Entrepreneurship Education Practice Platform
}

\author{
Shuo YANG \\ Jinlin Business and Technology College, China \\ yangyu1983@sina.com
}

Keywords: University science park, Innovation and entrepreneurship, Practice platform.

\begin{abstract}
The goal of the innovation and entrepreneurship education is to cultivate the students' innovation consciousness, pioneering spirit and entrepreneurial ability. Compared with traditional education mode, there are essential differences in the teaching methods, teaching methods and educational ideas. From the ideas of constructing new innovation and entrepreneurship education system, create a real environment for innovation and entrepreneurship education, establishing professional team of instructors for innovation and entrepreneurship education, renewing education concept and improving service consciousness of entrepreneurship incubation, a new approach of constructing innovation and entrepreneurship education practice platform was analyzed in this paper. A real entrepreneurial practice environment is built for students with e new teaching system and teaching environment, offering a good space and service team for students' entrepreneurship.
\end{abstract}

\section{Introduction}

The goal of the innovation and entrepreneurship education is to cultivate the students' innovation consciousness, pioneering spirit and entrepreneurial ability. Compared with traditional education mode, there are essential differences in the teaching methods, teaching methods and educational ideas. Especially the teaching practice, getting rid of classroom teaching, reproduces and practices a real entrepreneurial process. A real entrepreneurial practice environment is built for students with e new teaching system and teaching environment, offering a good space and service team for students' entrepreneurship[1-4].

\section{Construction of Innovation and Entrepreneurship Education System}

The cultivation of innovative spirit and entrepreneurial skills is one of the functions of universities. Colleges and universities must raise the status of innovation and entrepreneurship education to an equal importance to teaching research and academic research by making it going throughout the whole process of education. The teaching program for innovation and entrepreneurship education is designated in teaching system to combine and interact with professional education. In the curriculum arrangement and contents design, a comprehensive innovation and entrepreneurship curriculum system will be established.

The innovation education and entrepreneurship training of university are integrated with the innovative practice and entrepreneurial environment of university science park. Teaching methods, curriculum arrangement, innovation ability cultivation and job training are planned uniformly to establish an improved education system for innovative talents. Students are cultivated in a whole process from theories teaching, academic research, scientific research activities, entrepreneurship training and business practice. A diversified curriculum construction management system is formed combining basic theory teaching, specialized course teaching, entrepreneurship practice and coaching.

\section{Creating a Real Innovation and Entrepreneurship Education Environment}

Entrepreneurship education is a new and practical teaching method, which pays more attention to the practice of scientific and technological innovation and entrepreneurship training practice in the 
process of student training. University science and technology park, college business park, technology business incubator and other conditions are fully used to combine the teaching and practice education, building a platform of entrepreneurship practice to strengthen the combination of theory teaching, practice teaching and social practice teaching, and to integrate the innovation education and entrepreneurship training in colleges and universities and the innovation and entrepreneurship practice environment in science and technology parks as a whole. Students learn and experience in the real scientific research environment and entrepreneurial environment. Students are cultivated in a whole process from theories teaching, academic research, scientific research activities, entrepreneurship training and business practice. Students' ability of innovation and entrepreneurship are improved in the practice, and innovation and entrepreneurship education will be truly implemented.

University science and technology parks can create the most real entrepreneurial environment, and provide the most realistic innovation and entrepreneurship process. A lot of successful cases and failure cases give students practical, real and face to face education as teaching materials. As a scientific and technological enterprise incubator base, there are a number of small and micro enterprises start their business here, and a number of enterprises graduate here. These enterprises can provide space for students to practice. Students can go to these enterprises for internship to experience the entrepreneurial process by themselves, understanding the business operations like business planning, product development, manufacturing process, and product marketing. Students are given opportunity of learning innovation and entrepreneurship concepts of enterprises in university science parks, where their entrepreneurial awareness is improved and entrepreneurial skills are cultivated. By this way, innovation and entrepreneurship education is really implemented.

\section{Building Professional Team of Instructors for Innovation and Entrepreneurship Education}

The entrepreneurial instructor is the key of innovation and entrepreneurship education. According to statistics, the failure rate of college enterprises without entrepreneurial education is up to $80 \%$, and of those enterprises that accepted such education is about $30 \%$. It is an important process for students' entrepreneurship education to build a professional, specialized and expert team of instructors to guide students to carry out innovation activities and entrepreneurship practice.

Currently there are many innovative talents in colleges and universities, but fewer instructors experienced in entrepreneurship practice. In addition to grasping the entrepreneurial policies, familiar with the growth and development rules of enterprises, and understanding the resources required by the enterprise, instructors also need to have a certain forward-looking to guide the entrepreneurship and enterprise development. A group of outstanding scientific and technological workers and a number of successful entrepreneurs gather in the university science and technology parks. Some of them experienced in both theory and practice are invited to build a team of professional and part-time instructors. Innovation and entrepreneurship curriculums are set up to teach entrepreneurship cases, guide entrepreneurial practice, and implement tracking or counseling for college entrepreneurial team. They help students to develop business plan and complete venture project design, and guide the students to the enterprise management and market operation. Entrepreneurs are guided in venture enterprise registration, financial management, marketing and other aspects of practice, making the university science park an important platform for entrepreneurial talents cultivation of higher education and the carrier for organic combination of entrepreneurship education element systems.

\section{Renewing Management Concept and Improving Management System}

The National University Science Park is not only an important part of the national innovation system, but also an important base for independent innovation, an important part of Chinese higher education system, and an important platform for innovation and entrepreneurship talents training, which shoulders the important functions of cultivating innovation and entrepreneurship talents. It is the best base for entrepreneurship education practice of college and university students. It is 
inextricably linked with school teaching and scientific research. At the same time when providing familiar professional and scientific research achievements for entrepreneurs, it also provides technical support and practical platform for entrepreneurship as the best base for entrepreneurship education practice of college and university students.

As the last link of the innovation and entrepreneurship education system, entrepreneurship incubation is very important in the construction of students' entrepreneurship education practice platform. Business incubation is a basic function for all science and technology parks. However, different from ordinary small business, entrepreneurial enterprises of students are more delicate and fragile, needing more care and favor of university science and technology parks. For the particularity of such enterprises, university science parks should establish dedicated entrepreneurial incubator to provide small area of office space and office facilities for student entrepreneurs, allowing micro start-ups registering in its office, so that entrepreneurs can even start empty-handed. Improved entrepreneurial services and entrepreneurial instructors team are established to provide nanny one-on-one business counseling to students' entrepreneurship. Models of student entrepreneurial guidance services are established to provide high-quality incubator service for college student entrepreneurs, realizing entrepreneurial guidance and service everywhere.

\section{Conclusion}

As an excellent platform to assist college students' innovation and entrepreneurship, university science and technology parks are playing an active role. By fostering college students' innovation and entrepreneurship, they further promote the development of China's manufacturing enterprises, and impose a very positive effect on the implementation of China's strategy as a giant country in manufacturing.

\section{References}

[1]HAN Yan-Ming, Study on Concept, Education Concept and University Concept ,J.Educational Research.9(2003)55-56

[2]YU Qing-Chen, XU Ping. Practical Connotation of Teaching Mode Reform in Modern Classroom: A Reflection Perspective ,J.Educational Science Research.1(2014)15-18

[3]GUO Yu-Lian. Discussion on Reform of Teaching Mode in Classroom,J.Theory and Practice of Education.10(2012)57-60

[4]ZHU Hong. Research on Teaching Mode of College Classroom Reform,J.Education and Vocation.3(2011)106-107 